\title{
Aquatic Toxicology Notes: Predicting the Fate and Effects of Aquatic and Ditchbank Herbicides ${ }^{1}$
}

Chris Wilson $^{2}$

\section{INTRODUCTION}

The potential for a given pesticide to cause adverse effects on aquatic organisms depends on 1) its inherent toxicity to the specific organism and 2) the organism's exposure to the compound in terms of concentration and duration (Table 1). The inherent toxicity is a specific relationship between the organism and the chemical, which cannot be changed (i.e. specific mode of action). On the other hand, exposures can be highly variable due to a variety of factors including application rates and techniques, chemical and physical properties of the chemical and environmental conditions at the time of application.

The purpose of this document is to introduce readers to: 1) factors affecting the exposure of aquatic organisms to aquatic herbicides, and 2) useful methods for estimating potential risks of acute mortality for non-target aquatic organisms. A series of companion EDIS documents containing herbicide-specific information is accessible at http://edis.ifas.ufl.edu/ TOPIC_AQUATIC_TOXICOLOGY. These documents contain specific information

concerning chemical properties, environmental fate, toxicity to non-target organisms, and references.

\section{FACTORS INFLUENCING EXPOSURE OF NON-TARGET ORGANISMS TO AQUATIC HERBICIDES}

The fate of a pesticide refers to what happens to it once it is released into the environment. To describe the fate of a given pesticide, the environment is usually thought of as having several compartments, including: soil, water, air, and biota (living creatures) (Figure 1). The fate of a given pesticide is important because it ultimately dictates the duration (e.g. 1 hour, 1 day, 1 week, etc.) and route (e.g. sediments, food, water column, etc.) of exposure for aquatic organisms. Many factors influence the fate of pesticides in the environment, and the likelihood that aquatic organisms may be exposed to them. Herbicide application rates are important because

1. This document is SL236, a fact sheet of the Soil and Water Science Department, Florida Cooperative Extension Service, Institute of Food and Agricultural Sciences, University of Florida. Original publication date April 2006. Visit the EDIS Web Site at http://edis.ifas.ufl.edu.

2. Chris Wilson, assistant professor, Soil and Water Science Department, Indian River Research and Education Center--Ft. Pierce, FL; Florida Cooperative Extension Service, Institute of Food and Agricultural Sciences, University of Florida, Gainesville, FL 32611-0290.

All chemicals should be used in accordance with directions on the manufacturer's label. The use of trade names in this publication is solely for the purpose of providing specific information. UF/IFAS does not guarantee or warranty the products named, and references to them in this publication does not signify our approval to the exclusion of other products of suitable composition.

The Institute of Food and Agricultural Sciences (IFAS) is an Equal Opportunity Institution authorized to provide research, educational information and other services only to individuals and institutions that function with non-discrimination with respect to race, creed, color, religion, age, disability, sex, sexual orientation, marital status, national origin, political opinions or affiliations. U.S. Department of Agriculture, Cooperative Extension Service, University of Florida, IFAS, Florida A. \& M. University Cooperative Extension Program, and Boards of County Commissioners Cooperating. Larry Arrington, Dean 
Table 1. Factors affecting potential toxicity of an aquatic herbicide.

\begin{tabular}{|ll|}
\hline \hline \multicolumn{1}{c|}{ Factor } & \multicolumn{1}{c|}{ Description } \\
\hline Mode of Action & $\begin{array}{l}\text { Specific biochemical pathway that is impacted by the pesticide, resulting in negative effects such as } \\
\text { death, reduced reproduction, reduced health, or some other negative impact. }\end{array}$ \\
$\begin{array}{l}\text { Concentration } \\
\text { The actual amount of pesticide in the water column and/or sediments to which the organisms are } \\
\text { exposed. }\end{array}$ \\
$\begin{array}{l}\text { Exposure } \\
\text { Duration }\end{array}$ & $\begin{array}{l}\text { The amount of time the organism is exposed to the pesticide. The probability of toxic effects generally } \\
\text { increases as exposure duration increases if a mode of action is present. }\end{array}$ \\
\hline \hline
\end{tabular}

they dictate the total amount of active ingredient that organisms may be exposed to. In addition, the solubility and partitioning behavior of the herbicide will determine whether organisms in the water column or sediments will likely be exposed, and the persistence of the herbicide will influence the potential exposure period. These factors are discussed in the following sections.

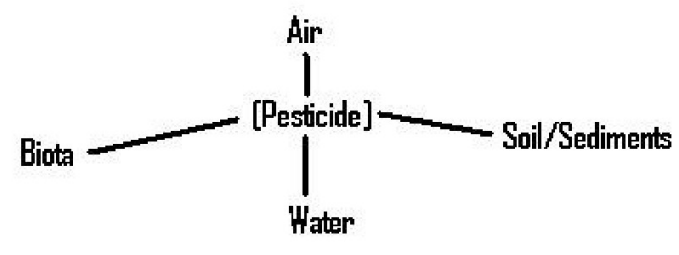

Figure 1. Distribution of a pesticide between the different environmental compartments.

\section{Water Solubility}

Water solubility refers to the amount of the pesticide that will completely dissolve in a given volume of water. When a solid or liquid completely dissolves in water, the resulting liquid mixture is clear with no suspended materials present. This is one of the most important properties influencing the presence of a pesticide in the water column. The typical units for expressing solubility are:

- g/L ( parts per thousand)

- $\mathrm{mg} / \mathrm{L}$ ( parts per million)

$\cdot \mu \mathrm{g} / \mathrm{L}(\sim$ parts per billion $)$
Note equivalents,

- $1 \mathrm{~g} / \mathrm{L}=1,000 \mathrm{mg} / \mathrm{L}=1,000,000 \mu \mathrm{g} / \mathrm{L}$

- $1 \mathrm{mg} / \mathrm{L}=0.001 \mathrm{~g} / \mathrm{L}=1000 \mu \mathrm{g} / \mathrm{L}$

- $1 \mu \mathrm{g} / \mathrm{L}=0.001 \mathrm{mg} / \mathrm{L}=0.000001 \mathrm{~g} / \mathrm{L}$

Because solubility is affected by temperature, solubility values are usually reported with the temperature at which they were measured. Pesticides having large water solubility values dissolve to a greater extent relative to those with smaller solubility values. For instance, a pesticide with a water solubility value of $33,000 \mathrm{mg} / \mathrm{L}$ at $80^{\circ} \mathrm{F}$ is 1000 times more soluble than one with a solubility of 33 $\mathrm{mg} / \mathrm{L}$ at $80^{\circ} \mathrm{F}$.

\section{Partitioning Behavior}

Once the herbicide is applied to the water or to surrounding ditch banks, it will preferentially move or transfer into one or more of the environmental compartments depending on the physical and chemical properties of the herbicide and the environment. By definition, partition refers to the act or process of distributing something into different phases or compartments. Two major partitioning routes influencing the fate of pesticides are 1) partitioning between soil/sediments and water, and 2) partitioning between soil/sediments/water and air. These concepts are discussed below.

\section{Soil-Water Partitioning}

When an herbicide is applied directly to the soil (ditchbanks) or water, some of it will preferentially sorb (stick) to soil particles, particularly organic matter (OM), and some will dissolve and mix with the water. The process of sorption greatly influences the partitioning of some chemicals into the soil and sediment environmental compartments. Sorption is a 
general term referring to the physical associations of an herbicide with the surface (adsorption) and the interior (absorption) of solid matrices. The sorptive properties of herbicides vary greatly. Those that are less strongly sorbed may be slowly released back into the water column through the process called desorption. Sorption can also influence the susceptibility of the herbicides to degradation processes in the environment by removing them from or attracting them to active degradation zones. The partitioning coefficient $\left(\mathrm{K}_{\mathrm{d}}\right)$ is an indicator of the sorptive properties of a pesticide (Figure 2). This value is calculated from experiments where a soil and water is mixed into a slurry along with the pesticide. Once equilibrium is achieved, the concentration of pesticide associated with the solids and dissolved fractions are measured. The $\mathrm{K}_{\mathrm{d}}$ is then calculated as,

[sorbed pesticide concentration] / [pesticide concentration in solution]

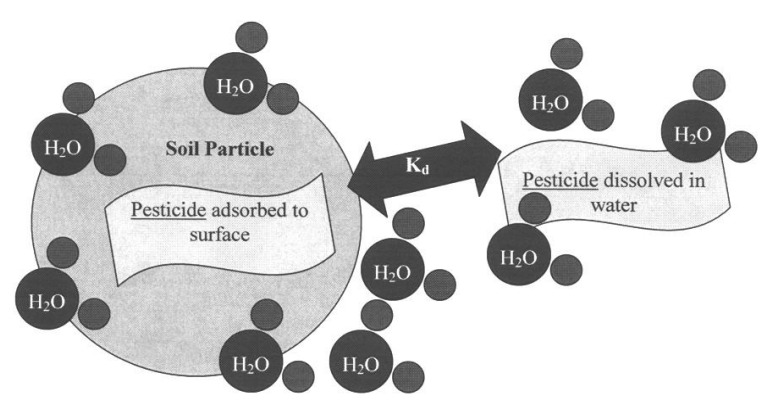

Figure 2. The partitioning coefficient $\left(\mathrm{K}_{d}\right)$ estimates the relative distribution of a pesticide between the sorbed and dissolved states.

$\mathrm{K}_{\mathrm{d}}$ values for a given herbicide, especially nonpolar compounds, can be used to qualitatively predict whether it will preferentially partition into the water column or sediments and soil (ditchbanks) using the following criteria:

- $\mathrm{K}_{\mathrm{d}}=1$; Equally distributed between solid and water
- $\mathrm{K}_{\mathrm{d}}>1$; More than $50 \%$ likely present in sorbed states

- $\mathrm{K}_{\mathrm{d}} \gg>1$; Most present is highly sorbed, very little in soluble state (water)

- $\mathrm{K}_{\mathrm{d}}<1$; More than $50 \%$ likely present in soluble state (water column)

- $\mathrm{K}_{\mathrm{d}} \ll<1$; Most present in highly soluble state, very little sorbed

For nonpolar pesticides, sorption is primarily related to associations with organic materials in the soil and sediments. Because of the importance of organic carbon, the Organic Carbon partitioning coefficient $\left(\mathrm{K}_{\mathrm{oc}}\right)$ is more commonly reported. The $\mathrm{K}_{\mathrm{oc}}$ is derived as,

$$
\mathrm{K}_{\mathrm{d}} / \mathrm{F}_{\mathrm{oc}}(\% \text { organic carbon in soil })
$$

If one has the $\mathrm{K}_{\mathrm{oc}}$ for one soil-pesticide combination (reported in literature), the $\mathrm{K}_{\mathrm{d}}$ for other soil types can be estimated by multiplying the $\mathrm{K}_{\mathrm{oc}}$ by the fraction (\%) of soil organic carbon $\left(\mathrm{K}_{\mathrm{oc}} \times \mathrm{F}_{\mathrm{oc}}\right)$. For a given nonpolar pesticide, sorption increases as the soil/sediment organic carbon content increases. Thus, pesticide leaching in ditch bank soils with high OM is expected to be slower compared to soils low in OM due to increased sorption. Pesticides with a $\mathrm{K}_{\text {oc }}$ or $\mathrm{K}_{\mathrm{d}}=0$ do not sorb to soil/sediment, and would likely move with the water in a totally dissolved state.

While sediments and soils are similar in many ways, it is important to note that pesticides may interact with each in very different fashions. Possibly contributing to the different behaviors is the increased amorphous material and organic matter content found in many sediments as opposed to soils.

The use of $\mathrm{K}_{\mathrm{oc}}$ for estimating sorptive potential is appropriate for nonpolar pesticides, and assumes that all partitioning is influenced primarily by hydrophobic (water-hating) interactions with insoluble organic materials. This may not be the case with ionizable pesticides. Ionizable pesticides are those in which the uncharged, neutral form is capable of gaining or losing protons, resulting in a change into cationic (positively charged) or anionic (negatively charged) forms relative to $\mathrm{pH}$. Pesticides capable of ionization are typically indicated by the 
presence of $\mathrm{pK}_{\mathrm{a}}$ or $\mathrm{pK}_{\mathrm{b}}$ values. When not in the neutral state, pesticides having a $\mathrm{pK}_{\mathrm{a}}$ will be anionic; while those with a $\mathrm{pK}_{\mathrm{b}}$ will be cationic. A summary of the expected environmental behavior of ionizable pesticides is shown in Table 2. Consult Wauchope et al. (1992) for a more thorough discussion.

Table 2. Summary of the expected environmental behavior of ionizable pesticides based on ionization constants. Table taken from Wauchope et al. (1992).

\begin{tabular}{|c|c|c|}
\hline $\begin{array}{c}\mathrm{pK}_{\mathrm{a}} / \mathrm{pK}_{\mathrm{b}} \\
\text { Value }\end{array}$ & $\begin{array}{c}\text { Dominant } \\
\text { form }^{1}\end{array}$ & Environmental Behavior \\
\hline $\mathrm{pK}_{\mathrm{a}}<3$ & anion & $\begin{array}{l}\text { Highly mobile in soil unless } \\
\text { chemical complex formed; } \\
\text { less mobile under very acidic } \\
\text { conditions; very soluble; } \\
\text { nonvolatile. }\end{array}$ \\
\hline $\mathrm{pK}_{\mathrm{a}}>10$ & neutral & $\begin{array}{l}\text { Behaves like nonionic } \\
\text { material except at extremely } \\
\text { high pH; less mobile than } \\
\text { anion; probably much less } \\
\text { soluble than anion; } \\
\text { volatilization possible. }\end{array}$ \\
\hline $\mathrm{pK}_{\mathrm{a}}$ 3-10 & $\begin{array}{l}\text { mixture of } \\
\text { neutral } \\
\text { and anions } \\
\text { depending } \\
\text { on pH }\end{array}$ & $\begin{array}{l}\text { If } \mathrm{pH} \text { is near the } \mathrm{pK} \text {, } \\
\text { mobility, solubility and } \\
\text { volatility will be sensitive to } \\
\mathrm{pH} \text {. }\end{array}$ \\
\hline $\mathrm{pK}_{\mathrm{b}}<4$ & cation & $\begin{array}{l}\text { Immobile (clay surface } \\
\text { sorption); very soluble; } \\
\text { extreme soil sorption leads } \\
\text { to long half-life but little } \\
\text { biological activity; nonvolatile. }\end{array}$ \\
\hline $\mathrm{pK}_{\mathrm{b}}$ 4-11 & $\begin{array}{l}\text { mixture of } \\
\text { neutral } \\
\text { and anions } \\
\text { depending } \\
\text { on pH }\end{array}$ & $\begin{array}{l}\text { If } \mathrm{pH} \text { is near } \mathrm{pK}_{\mathrm{b}} \text {, mobility, } \\
\text { solubility, and volatility will be } \\
\text { sensitive to } \mathrm{pH} \text {. }\end{array}$ \\
\hline $\mathrm{pK}_{\mathrm{b}}>11$ & neutral & $\begin{array}{l}\text { Behaves like nonionic } \\
\text { material except at extremely } \\
\text { low pH; much more mobile, } \\
\text { and less soluble than cation; } \\
\text { volatilization possible. }\end{array}$ \\
\hline \multicolumn{3}{|c|}{${ }^{1}$ Assumes soil $\mathrm{pH}$ ranges from $5-8$. } \\
\hline
\end{tabular}

Sorption mechanisms for these pesticides include:

1. binding of cations (positively charged herbicides) to negatively charged sites on clay surfaces (very strong interaction)

2. binding of anions (negatively-charged herbicides) to soil anion-exchange sites (a very weak interaction)

3. chemical specific binding mechanisms.

\section{Soil/Water-Air Partitioning}

One other partitioning behavior affecting exposure of nontarget organisms is between the solid or liquid state and air. This behavior is primarily influenced by the vapor pressure or volatility of the pesticide. Volatility is the tendency for a liquid or a solid to change into a gas. It describes how quickly a liquid will evaporate when it is in contact with air. Highly volatile chemicals are easily lost to the atmosphere. Chemical volatility is generally inversely related to water solubility (i.e. highly water soluble compounds are not very volatile and vice versa).

\section{Environmental Persistence}

The persistence of the herbicide in the environment refers to how long it remains in a biologically active or inactive (for degradation products) form. The typical measure of persistence is called the half-life $\left(\mathrm{T}_{1 / 2}\right)$, or the amount of time needed for half of the chemical to disappear. The $T_{1 / 2}$ of pesticides is highly variable. In fact, the same pesticide may have a very different $T_{1 / 2}$ in various environments. Persistence increases as the $\mathrm{T}_{1 / 2}$ increases, and is highly influenced by the susceptibility of the herbicide to a variety of degradative processes such as: photodecomposition, microbial decomposition, and chemical degradation. These are discussed below.

\section{Photodecomposition}

Photodecomposition reactions account for the degradation of many herbicides in both aquatic and terrestrial environments. These reactions require absorption of light energy by the herbicide molecule in order to progress. Substances that absorb UV light in the spectral region of sunlight (Wavelengths $>290$ $\mathrm{nm}$ ) may either (1) undergo direct photolysis, or (2) 
undergo indirect photolysis in which other constituents in the water absorb the light energy, which is either transmitted to the herbicide (sensitization) or leads to the formation of reactive species that enter into chemical reactions. Water turbidity (the presence of suspended sediments and foreign particles) directly affects light penetration into the surface water, and indirectly affects light absorption by the herbicides. Thus, the half-life for an herbicide that is normally readilly photodegraded may be extended when applied in conditions where light penetration into the water column is limited. This increased half-life may also extend the exposure time for aquatic organisms.

\section{Microbial Decomposition}

The uppermost sediment layer in a surface water body is the most biologically active area, and encompasses the primary reaction zone for sorptive and microbially-mediated degradative processes. Microbial populations within the uppermost strata may be 10 times greater than in lower strata (i.e., 1 meter). As a result of microbial respiration, dissolved oxygen concentrations decrease causing changes in localized water chemistry. These changes in chemistry favor the accumulation of organic matter, which provides additional adsorbent and an energy source for microbial respiration and possible degradation of some pesticides.

\section{Water Chemistry}

Water $\mathrm{pH}$ can affect the adsorption of some pesticides to sediments, especially those that are ionizable (have a pK value). Lake water sometimes possesses higher $\mathrm{pH}$ values than the incoming water. As a result, weakly basic pesticides such as substituted ureas (i.e. diuron), and acidic herbicides (i.e. 2,4-D) may desorb from sediment/soil complexes. Often, $\mathrm{pH}$ values approaching the $\mathrm{pK}$ of specific compounds results in maximum adsorption to organic matter. Changes in $\mathrm{pH}$ may also result in increased desorption of pesticides from sediments and in some cases $\mathrm{pH}$ has no effect on adsorption/desorption phenomena. Basic compounds are sorbed most strongly when the surface acidity of the soil/sediment particle is 1 to $2 \mathrm{pH}$ units lower than that of the lowest $\mathrm{pK}$ value of the molecule. In addition to its influence on sorption, $\mathrm{pH}$ also stimulates hydrolysis of some pesticides. Hydrolysis refers to the breakdown of the active ingredient by reactions with water molecules.

\section{Limnology}

Pond characteristics such as water body size, depth, thermal stratification, and lake age can have important effects on mixing, water chemistry, and sediment distribution within the water body. The effects on mixing are especially important during herbicide applications. If the water is not well mixed, herbicide concentrations may be much higher in the uppermost strata, possibly intensifying toxicity to target and non-target organisms. Stratification within ponds may also change the water chemistry due to the lack of oxygen exchange to bottom areas. The resulting conditions may increase or decrease degradation of specific herbicides. Sediment distribution effects are especially important relative to the input of pesticide-containing soil eroded from ditchbanks and other areas. In this case, the sorbed complexes segregate on a particle size basis with the largest sized particles remaining close to the runoff inflow points and the smaller sized particles moving progressively farther from the inflow point based on decreasing density. Clay distribution is usually more uniform in small ponds that are subjected to large inflows of runoff and no stratification. These clay particles eventually settle to the bottom and distribute vertically according to size.

\section{AQUATIC TOXICOLOGY}

\section{Basic Principles}

Aquatic toxicology can be defined as the study of the effects of potentially toxic chemicals on aquatic organisms, with special emphasis on the harmful effects. Historically, this discipline has used toxicity tests to identify the harmful effects. Standard tests 
evaluate dose-response relationships

(toxicity at different concentrations) and mechanisms of action in a variety of organisms that are representative of different ecosystem niches. These tests may evaluate the response of individuals or populations to varying concentrations of the chemical. The dose-response relationship is based on the following three assumptions:

1. The response (toxicity) is due to the chemical administered

2. The magnitude of the response (toxicity) is related to the dose

3. There exists both a quantifiable method for measuring and a precise means of expressing toxicity.

\section{Types of Effects}

Effects may be of such minor significance that the organism can function normally. However, under stressful conditions (i.e., $\mathrm{pH}$ change, low dissolved oxygen, high temperatures, changes in hardness, etc.), the same chemical exposure may become very lethal. The toxicity of some chemicals may also be enhanced or mitigated in the presence of other chemicals. In addition to killing the organisms, some pesticides can have negative but non-lethal effects on individual organisms and populations, such as reduced reproduction, reduced mobility to escape predation, or alterations in behavior.

\section{Toxicity Measurement and Estimation}

One common measurement used to describe toxicity of pesticides to organisms is the $\mathrm{LC}_{50}$, or the statistically derived concentration in water that can be expected to cause death in 50 percent of the animals exposed (Figure 3).

For estimation of non-lethal effects on processes such as growth and reproduction, the $\mathrm{EC}_{50}$, or the statistically derived concentration in water that can be expected to cause a reduction of 50 percent in the process being measured, is used. Toxicity tests

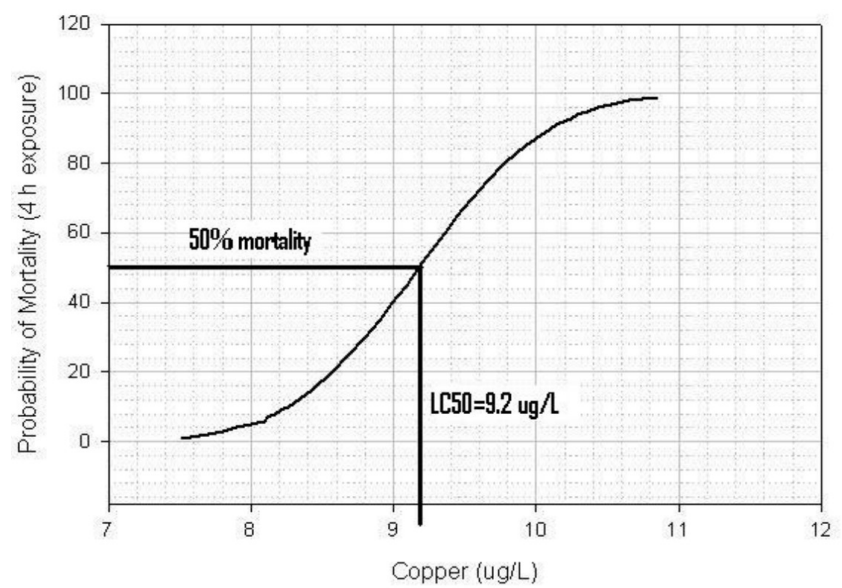

Figure 3. Sample toxicity curve showing water flea mortality. The sigmoidal line represents actual percent mortality. The $\mathrm{LC}_{50}=9.2 \mu \mathrm{g} / \mathrm{L}$ in this example.

usually fall into one of two catagories, acute or chronic. Acute tests are designed to evaluate the effects of pesticides on survival following exposures for a short period of their lifespan. Animals used in these tests are normally exposed for 24-, 48-, 72-, or 96 hours in order to estimate acute toxicity. In contrast, chronic toxicity tests evaluate effects over a significant portion $\left(1 / 10^{\text {th }}\right.$ of lifetime or longer) of the organism's life span. These tests often evaluate sublethal effects on reproduction, growth, and behavior, as well as mortality. Relative to acute effects, chronic effects may occur following exposures to lower concentrations of the pesticide. This chronic toxicity information is not always readily available because of the considerable expense associated with testing.

\section{Standard Toxicity Testing Organisms}

It is important to recognize that toxicity data will not always be available for all potential species in a given environment. Given this limitation, the overall objective of test organism selection is to choose surrogates that are representative of the major ecosystem components. Aquatic algae and plants are representative of organisms that convert sunlight to carbon-based energy (the base of the food chain). Invertebrate species such as scuds and water fleas feed on algae and decaying plant materials and bacteria. These organisms are an important food source for larger invertebrates and fish. Fish species 
serve as an important source of food for a variety of larger fish, birds and mammals. Fathead minnows and sunfish often represent temperate warm-water fish, and trout represent coldwater fish species.

A listing of commonly used species in North America is provided in Tables 3, Table 4 and Table 5, along with a brief description of the significance of each. Of those listed, several organisms are more routinely used for estimating pesticide toxicity because of their sensitivities, ease of culturing, and because much is known about their life histories (i.e. physiology, genetics, behavior, etc.). These organisms include: water fleas (Daphnia sp.), fathead minnows (Pimephales promelas), bluegill (Lepomis macrochirus), rainbow trout (Oncorhynchus mykiss/Salmo gairdneri), mysid shrimp (Mysidopsis sp.), and sheepshead minnow (Cyprinodon variegatus). The use of these surrogates assumes that organisms within a group will respond similarly, which may not always be the case (see "Note Uncertainty" section for more information).

\section{RISK ESTIMATION}

The risk of toxicity between a given herbicide and aquatic organism depends on the organism-specific, inherent toxicity of the compound and the concentration and duration of the exposure. The inherent toxicity is associated with the presence of a specific mode-of-action for causing toxic effects, and cannot be changed. The exposure concentration and duration can be affected by all of the processes discussed in the previous sections.

Herbicides labeled for application directly to aquatic systems or to ditch banks may be of special concern in aquatic systems because of the more direct exposure routes, compared to applications in a terrestrial situation. While the labels for these herbicides have been formulated to minimize potential toxicity in treated water bodies, it is important to recognize that there is a margin of safety associated with use of each at the labeled application rates; and that margin of safety can be significantly reduced with improper use.
There are several methods for estimating the potential risks of toxicity to nontarget organisms. Below are descriptions of several common methods that may be useful for estimating risks to aquatic organisms.

Note Uncertainty. Uncertainty refers to doubt associated with estimation. When trying to predict the ecological risks of any chemical to aquatic organisms, it is important to recognize sources of uncertainty within the estimate. Differing degrees of uncertainty exist for all aspects of a risk assessment, from estimating exposures to effects on the organism. Results of toxicity assays can be influenced by many factors including the initial health of testing-organisms, age and sex of the organisms, as well as treatment of those organisms before and during toxicity assays. Results generated in the lab may exaggerate or understate toxicity for a given species under actual local conditions in the environment. Likewise, organisms may vary in their response to pesticide exposures between species, genera, families, etc. Thus, results from toxicity tests should not be considered as absolute values, but rather as possible values occurring within a range of probable values. These values are especially useful for comparing relative toxicity of pesticides to organisms. The common practice when toxicity data are not available for a given species within the environment of interest is to use a related species. It should be recognized that the response of the chosen species may or may not be similar.

\section{Ratio of Environmental Concentration / Toxic Concentration}

One simple (but less precise) toxicity screening method is to compare expected environmental concentrations of the pesticide to levels causing toxicity to relevant organisms in that environment. Environmental concentrations greater than the levels causing toxicity constitute significant risks. This approach is useful as a screening tool, and is easy to calculate with herbicides applied directly to the water in order to achieve a target concentration. However, estimation of concentrations in the water resulting from ditchbank or drained-ditch/pond applications is more difficult because of partitioning and degradation uncertainties. Estimation of environmental concentrations in these situations may 
be made using sophisticated models that account for the chemical and environmental properties discussed earlier.

The US EPA uses this method as a screening tool for pesticides during the registration process. Using their guidelines, a risk quotient $(\mathrm{RQ})>0.5$ indicates high acute risks; an RQ $>0.1$ indicates acute risks that may be mitigated using restrictions; and an RQ $>0.05$ indicates acute risks to endangered species.

\section{FDEP Criteria}

The Florida Department of Environmental Protection (FDEP) bases their narrative water quality criteria for pesticides on the 96-hour $\mathrm{LC}_{50}$, or the concentration of pesticide that is lethal to $50 \%$ of the test organisms after 96 hours of exposure. According to these criteria, the acute and chronic toxicity thresholds are calculated as one-third and one-twentieth of the lowest 96-hour $\mathrm{LC}_{50}$ determined for the most sensitive species present in the aquatic system of interest. By basing these criteria on the $\mathrm{LC}_{50}$ of the most sensitive species in the system, the assumption is that all other organisms should be protected.

\section{Species Sensitivity Distribution}

Living aquatic organisms vary greatly in taxonomy, life histories, physiology, morphologies, behaviors, and geographical distributions. From an ecotoxicology perspective, these differences mean that different species may respond differently to a compound at a given concentration.

Acknowledgment that different species have different sensitivities and the need to describe that variation with a statistical distribution function resulted in the development of species sensitivity distributions.

A species sensitivity distribution is a graph plotting the $\mathrm{LC}_{50} / \mathrm{EC}_{50}$ concentrations for organisms within the aquatic environment ( $\mathrm{x}$-axis) versus the cumulative probability for its occurrence (y-axis) (Figure 4). The $\mathrm{LC}_{50} / \mathrm{EC}_{50}$ concentrations are arranged from lowest to highest, with the most sensitive organisms occurring toward the lower herbicide concentrations (lower left corner of the plot) and less sensitive organisms occurring towards the higher concentrations (upper right hand corner). All of the data included in the plot should be for the same exposure / measurement time interval (i.e. 24-, 48-, 96 hours, etc.).

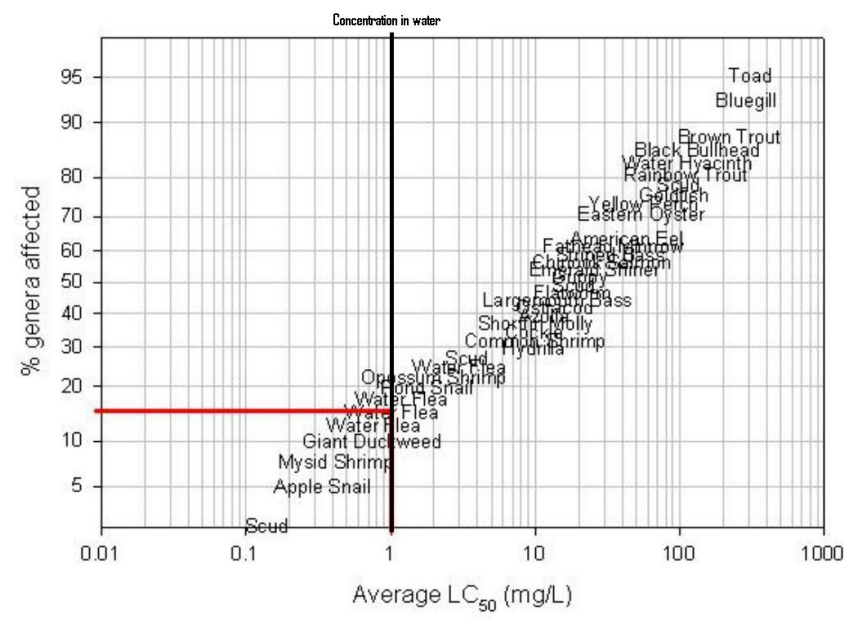

Figure 4. Example of a species sensitivity distribution. Species sensitivity decreases as concentration increases. The vertical line on the plot represents a hypothetical concentration in the water following treatment. Organisms appearing on the left-side of that line would likely be affected by the herbicide, while those to the right would not.

These plots can be interpreted in two ways. First, potential organisms at risk (acute mortality) due to herbicide applications can be visualized by drawing a vertical line on the plot at the treatment target concentration (for herbicides with target water column concentrations). Organisms appearing on the left-side of that line would likely be affected by the herbicide, while those to the right would not. Since information regarding toxicity to all organisms may not be available for a given herbicide, the second interpretation is more generic. In this case, the $\mathrm{LC}_{50} / \mathrm{EC}_{50}$ distribution represents the world of possible species in the system of interest and the percent of genera possibly affected is read off of the $\mathrm{y}$-axis. This is accomplished by drawing a line from the target concentration- $\mathrm{LC}_{50} / \mathrm{EC}_{50}$ intersection point to the y-axis. Using the hypothetical example in Figure $4,15 \%$ of the aquatic genera are predicted to be at risk at a water column concentration of $1 \mathrm{mg} / \mathrm{L}$.

\section{REFERENCES}

Hoffman, D.J., B.A. Rattner, G.A. Burton, Jr., and J. Cairns, Jr. (eds). 2002. Handbook of Ecotoxicology, 2nd Edition. Lewis Publishers, Boca Raton, FL. 
Merrit, R.W. and K.W. Cummins. 1996. An

Introduction to the Aquatic Insects of North

America, 3rd edition. Kendall/Hunt Publishing

Company, Dubuque, IA.

Pennak, R.W. 1989. Freshwater Invertebrates of

the United States, 3rd Edition. John Wiley \&

Sons, Inc, New York.

Ruppert, E.E., R.S. Fox, and R.D. Barnes. 2004.

Invertebrate Zoology: A Functional Evolutionary

Approach, 7th edition. Brooks/Cole-Thomson

Learning, Belmont, CA.

Wauchope, R. D., Buttler TM, Hornsby AG, Augustijn-Beckers PWM, Burt JP. 1992. The SCS/ARS/CES pesticide properties database for environmental decision-making. Rev Environ Contam Toxicol 123:1-164. 
Table 3. Listing of common fish used for toxicity testing in North America, and their ecological significance.

\begin{tabular}{|llll|}
\hline \hline \multicolumn{1}{|c}{ Common Name } & \multicolumn{2}{c|}{ Latin Name } & \multicolumn{1}{c|}{ Description and Ecological Significance } \\
\cline { 1 - 2 } Bluegill & $\begin{array}{l}\text { Lepomis } \\
\text { machrochirus }\end{array}$ & $\begin{array}{l}\text { One of largest and most common sunfish; native to eastern/central North America; } \\
\text { Habitat: shallow, weedy, warm water of lakes, ponds, and heavily vegetated slowly } \\
\text { moving areas of small rivers and larger creeks. }\end{array}$ \\
Fhannel catfish & Ictalurus punctatus & $\begin{array}{l}\text { Commercially significant; freshwater fish; Range: throughout North America; feeds } \\
\text { on small fish, crustaceans (i.e. crayfish), clams, snails, aquatic insects, and small } \\
\text { mammals. }\end{array}$ \\
\hline Rainbow trout & $\begin{array}{l}\text { Pimephales } \\
\text { promelas } \\
\text { Oncorhynchus } \\
\text { mykiss }\end{array}$ & $\begin{array}{l}\text { Small, warm/fresh water species; Habitat: ponds, lakes, ditches, slow muddy } \\
\text { streams; omnivorus, feeding on living invertebrates and detritus; widely distributed. } \\
\text { Cold/fresh water species; widespread in NE North America east of the Mississippi } \\
\text { river. Economically important. }\end{array}$ \\
\hline $\begin{array}{l}\text { Sheepshead } \\
\text { minnow }\end{array}$ & $\begin{array}{l}\text { Cyrinodon } \\
\text { variegatus }\end{array}$ & $\begin{array}{l}\text { Grows up to 3 inches long; tolerant of high temperatures and salinities; typically } \\
\text { found in estuaries; shallow water. }\end{array}$ \\
\hline \hline
\end{tabular}

Table 4. Listing of common aquatic plants used for toxicity testing in North America, and their ecological significance.

\begin{tabular}{|llll|}
\hline \hline \multicolumn{1}{c|}{ Common Name } & \multicolumn{1}{c|}{ Latin Name } & \multicolumn{1}{c|}{ Description and Ecological Significance } \\
\cline { 2 - 2 } Duckweed & Lemna sp. & $\begin{array}{l}\text { Small }(2-4 \mathrm{~mm}) \text { floating plant; food source for water fowl and small animals; } \\
\text { provides food, shelter, and shade for fish; provides physical support for various } \\
\text { invertebtrates. }\end{array}$ \\
\hline Marine algae & $\begin{array}{l}\text { Selenastrum } \\
\text { capricornutum }\end{array}$ & $\begin{array}{l}\text { Representative of freshwater primary producers, which are the base of freshwater } \\
\text { aquatic food chains. }\end{array}$ \\
\hline \hline
\end{tabular}

Table 5. Listing of common aquatic invertebrate organisms used for toxicity testing in North America, and their ecological significance.

\begin{tabular}{|c|c|c|}
\hline Common Name & Latin Name & Description and Ecological Significance \\
\hline $\begin{array}{l}\text { Amphipods/Scuds/ } \\
\text { Sideswimmers }\end{array}$ & Hyalella azteca & $\begin{array}{l}\text { Widely distributed throughout North American fresh and marine waters; Habitat: } \\
\text { wide variety of unpolluted lakes, ponds, streams, brooks, springs,pools, and lakes; } \\
\text { found in vegetation or hidden under and between debris and stones during day; } \\
\text { typically found in shallow }(<1 \mathrm{~m}) \text { waters. Valuable food source for larger organisms. }\end{array}$ \\
\hline Grass shrimp & $\begin{array}{l}\text { Palaemonetes } \\
\text { pugio }\end{array}$ & $\begin{array}{l}\text { Small (1-2 inches), non-edible shrimp; transparent; usually found in estuaries; feed } \\
\text { on algae and detritus in grasses of salt marshes and salt ponds; use same grasses } \\
\text { for shelter. }\end{array}$ \\
\hline Marine amphipods & $\begin{array}{l}\text { Rheopoynius } \\
\text { pugio/Ampleisca } \\
\text { abdita }\end{array}$ & $\begin{array}{l}\text { Marine invertebrate; omnivorus, consume all kinds of plant and animal matter; } \\
\text { seldom predacious; important food species for small fish. }\end{array}$ \\
\hline Marine clam & Macoma sp. & $\begin{array}{l}\text { Marine shellfish; bivalve, wafer-thin shells; found in sand or mud; grow up to } 4 \\
\text { inches long; found } 4-6 \text { inches below surface of water in the middle of the intertidal } \\
\text { zone. }\end{array}$ \\
\hline Marine mussel & Mytilus edulis & $\begin{array}{l}\text { Marine shellfish; roughly triangular-shaped, hinged shells (bivalve); commonly } \\
\text { found in estuaries and from the middle shore to shallow sublittoral zone; filter feeds } \\
\text { on bacteria, plankton, and detritus; serves as food for whelks, crabs, sea urchins, } \\
\text { starfish, sea birds, and other animals. }\end{array}$ \\
\hline
\end{tabular}


Aquatic Toxicology Notes: Predicting the Fate and Effects of Aquatic and Ditchbank....

Table 5. Listing of common aquatic invertebrate organisms used for toxicity testing in North America, and their ecological significance.

\begin{tabular}{|c|c|c|}
\hline Common Name & Latin Name & Description and Ecological Significance \\
\hline Marine worms & Nereis virens & $\begin{array}{l}\text { Burrow in muddy sand areas of the littoral and sublittoral zones in both marine and } \\
\text { estuarine habitats; found throughout northern hemisphere; preys on invertebrates, } \\
\text { carrion, and algae; up to } 8 \text { inches long. }\end{array}$ \\
\hline Mayflies & Hexagenia sp. & $\begin{array}{l}\text { Habitat: lentic and lotic depositional sand-silt; burrowers; collectors-gatherers, } \\
\text { possibly filtering at mouth of burrow; widespread. }\end{array}$ \\
\hline Midges & Chironomus sp. & $\begin{array}{l}\text { Burrowers found in lentic-littoral and profundal, lotic depositions sediments; } \\
\text { widespread; herbivores, feeding as collectors-gathers, shredders. }\end{array}$ \\
\hline $\begin{array}{l}\text { Mysid (opposum) } \\
\text { shrimp }\end{array}$ & Mysidopsis bahia & Salt water, colorless shrimp; very important invertebrate predator. \\
\hline Oysters & $\begin{array}{l}\text { Crassostrea } \\
\text { virginica }\end{array}$ & $\begin{array}{l}\text { Shellfish with two rough shells hinged togther; typically } 2-6 \text { inches long; filter } \\
\text { feeders, feeding on plankton and detritus; range includes eastern shore of North } \\
\text { America and the Gulf of Mexico. }\end{array}$ \\
\hline Penaid shrimp & Penaeus sp. & $\begin{array}{l}\text { Commercially important; salt water; range generally restricted to Atlantic coast and } \\
\text { Gulf of Mexico; omnivorus (eat both plants and animals); bottom feeders; may } \\
\text { spawn in estuaries or sea. }\end{array}$ \\
\hline Water fleas & Daphnia sp. & $\begin{array}{l}\text { Ubiquitously distributed in freshwater bodies; ecologically important because they } \\
\text { convert phytoplankton and bacteria into animal protein and form a major portion of } \\
\text { the diet for many small fish species; relatively short lifecycle. }\end{array}$ \\
\hline
\end{tabular}

